\title{
Modeling the process of future physical education teachers' training for innovative educational activities
}

\author{
Maxim Popov ${ }^{1}$, Oksana Zorina ${ }^{2}$, and Lyubov Savchenko ${ }^{3}$ \\ ${ }^{1}$ V.I. Vernadsky Crimean Federal University, Department of Health and Rehabilitation, Republic of \\ Crimea, Simferopol, Prospekt Vernadskogo 4, Russia \\ ${ }^{2}$ V.I. Vernadsky Crimean Federal University, Department of Health and Rehabilitation, Republic of \\ Crimea, Simferopol, Prospekt Vernadskogo 4, Russia \\ ${ }^{3}$ V.I. Vernadsky Crimean Federal University, Department of Health and Rehabilitation, Republic of \\ Crimea, Simferopol, Prospekt Vernadskogo 4, Russia
}

\begin{abstract}
The article deals with the currently essential problem of improving the quality of future physical education teachers' training in accordance with the innovative development trends in the Russian Federation. The authors place special emphasis on the modeling of the training process of Bachelors in Physical Education. The article provides insight into the concept of "physical education teachers' innovative educational activity". The main content of the paper considers the theoretical substantiation of the structural and logical model as a theoretical construct of training Bachelors in Physical Education for this type of activity. The authors highlight the model's methodological, substantive, procedural and logical elements, which imply future teachers' mastering the optimal level of readiness for innovative educational activities.
\end{abstract}

\section{Introduction}

The top priorities of the state's social and economic policy in the sphere of human development are regulated by the Concept of long-term socio-economic development of the Russian Federation till 2020. In the context of our research, the most significant trends in this sphere's development include the promotion of health-oriented lifestyle standards, transition to individualized continuous education accessible to all people and introduction of innovative technologies in education solving the staffing problem [1].

According to the "Education Development" State Program of the Russian Federation for $2018-2025$, one of the spheres of the country's innovative development is the renovation of general education by increasing the attractiveness of the teaching profession and the level of the teaching staff's qualifications [2].

At the same time, the changes in the geopolitical situation, people's way of life, structural transformations in public life associated with the new coronavirus infection

\footnotetext{
* Corresponding author: zorina.oksana2017@mail.ru
} 
COVID-19 have caused a number of new challenges. In the draft Strategy for the Development of Physical Education and Sports in the Russian Federation for till 2030, special attention is paid to key challenges in the sphere of physical education and sports. These include changing people's values, their choice of alternative (inactive) forms of leisure and recreation, an increase in the number of people suffering from various health deviations caused by physical inactivity, a sharp decrease in the demand for services in the field of physical education and sports in 2020 and a significant negative impact of quarantine restrictive measures on the sports industry, the need to reduce expenditures on physical education and sports due to the pandemic, insufficient resource provision in the sphere of physical education and sports including the system of professional education [3].

The above-mentioned document analysis stipulates a social mandate to improve the quality of future physical education teachers' training in order to meet the requirements of the Russian Federation's innovative development. The research conducted by D.I. Voronin and I.F. Filchenkova is especially noteworthy, as the authors prove the need for reforming the sphere of higher education revising its theoretical and methodological foundations and introducing innovations. For instance, they stress that starting from the level of designing a basic educational program as a complex regulatory document of higher education it is necessary to set innovative goals, thus providing for innovations in the process and result of educational institutions' activities [4].

Analyzing the problem of modeling the process of future physical education teachers' training, scientists emphasize the importance of contextual and project-based training (V.V. Ishchuk [5]), design functional competencies (R.T. Gadzhimuratova [6]), natural science training (P.V. Khomenko [7]) and innovative educational technologies (N.G. Yershova, S.N. Bekasova [8]).

Over the recent years, a number of researchers have focused on the issues of providing students of higher educational institutions with the right not only to choose a learning model but also to develop programs aimed at their professional qualities' formation by means of implementing educational routes. Nowadays, teachers should be able to immerse students in the information and educational system including the distance learning system, where they have to transform the information provided in a ready-made form into their own discoveries and generate innovative products of educational activity [4, 9].

The group of authors (D.K. Beybalaeva, E.R. Guzueva, B.S. Sadulaeva) note that teachers, being organizers and coordinators of innovative activities, along with the other members of the educational community conduct the process of creating, using and disseminating pedagogical innovations. The uniqueness of innovations' life cycles lies in the attempt to overcome the contradiction between the traditional way of life and the modern requirements of the world community [10].

I.F. Filchenkova's viewpoint is the most reasoned one in this aspect, proposing university teachers' involvement in innovative activities through their participation in innovative projects contributing to the formation of their innovative orientation and increasing their innovative efficiency [9]. One cannot but notice that despite the seeming multidimensionality and vastness of the research, the mechanism of modeling the process of future physical education teachers' training in innovative educational activity requires additional consideration and elaborate study.

\section{Methods}

When writing an article, methods of analysis of scientific literature, periodic articles, and publications on the topic were used. 
The purpose of the research is to develop a model facilitating an increase in the efficiency of future physical education teachers' training process concerning innovative educational activities.

To compass the purpose, the following tasks were set:

1. To define the essence of the concept "physical education teachers' innovative educational activity".

2. To underpin theoretically the model of training Bachelors in Physical Education in innovative educational activity.

\section{Results}

Proceeding from the data of modern pedagogy on the issues under consideration, as well as on the results obtained in the course of generalization and analysis of the existing experience, we have come to the conclusion that it is impossible to implement educational innovations without teachers practicing innovative educational activities, educational innovations (innovative educational activities) and managerial innovations (innovative management activities). In our research on the professional training process, we will restrict ourselves to local educational innovations in Bachelor in Physical Education training, which presuppose being ready for this type of activity [11].

By Physical Education teachers' innovative educational activity, we mean purposeful and conscious creative activity based on the advanced and innovative experience of teaching physical education at secondary schools, meeting the requirements of the Federal State Educational Standard of General Education and consisting in the active use of innovative teaching technologies [12].

One cannot but agree with Y.E. Rupasova that in order to implement innovative activities, students must have a clue of what innovations mean, be able to think innovatively and have a certain model of innovative behavior manifested in their innovative orientation [13].

Consequently, innovative educational activity will be successful only if Bachelors in Physical Education are aware of the practical significance of educational innovations at the professional and personal levels. Therefore, before teachers are directly involved in the innovative educational process, it is important to take into account the level of their readiness for innovative educational activities.

In pedagogical research, the modeling mechanism should be considered as a set of sequential operations: the transition from a natural object to the construction of a model, the experimental study of its effectiveness and the transfer of the obtained results to a specific subject of research [7].

The structural and logical model as a theoretical construct of readiness for innovative educational activity based on the relationship of methodological, substantive and procedural and logical elements of future physical education teachers' training is presented in Figure 1.

According to the methodological element, the model's implementation is aimed at improving the quality of future physical education teachers' training in order to meet the requirements of the Russian Federation's innovative development.

As practice shows, teaching future Bachelors in Physical Education how to participate in innovative activities stipulates their professional development. They are influenced by both objective and subjective pedagogical conditions. These include training's professional and pedagogical orientation, the content of the educational process, the unity and interconnection of training's educational and practical aspects $[11,13]$.

In our research, pedagogical conditions were aimed at stimulating students' motivation for self-education and self-development, ensuring the personality-oriented nature of future physical education teachers' training, monitoring the quality of students' mastery of the 
components of readiness for innovative activities and ensuring the reflection process of their professional development [12].

\begin{tabular}{|c|c|c|}
\hline \multicolumn{3}{|c|}{ METHODOLOGICAL ELEMENT } \\
\hline \multicolumn{3}{|c|}{$\begin{array}{l}\text { Social mandate: improving the quality of future physical education teachers' training in order to meet } \\
\text { the requirements of innovative development of the Russian Federation }\end{array}$} \\
\hline \multicolumn{3}{|c|}{ Pedagogical conditions } \\
\hline Approaches & & Principles \\
\hline \multicolumn{3}{|c|}{ CONTENT-RELATED ELEMENT } \\
\hline Criteria & Levels & Diagnostic materials \\
\hline \multicolumn{3}{|c|}{ PROCEDURAL AND TECHNOLOGICAL ELEMENT } \\
\hline Training stages & Teaching methods & Subjects in the curriculum \\
\hline The result is the best possib & $\begin{array}{l}\text { future physical educ } \\
\text { educational activitie }\end{array}$ & hers' readiness for innovative \\
\hline
\end{tabular}

Fig. 1. The model of training future physical education teachers for innovative educational activities.

The design of the professional training process was based on the following points:

- the systematic approach allows identifying the structural components of future physical education teachers' readiness for innovative educational activities;

- the personality-oriented approach assumes a shift in emphasis on the student's personality as the subject of innovative educational activity and the object of targeted influences;

- the resource approach ensures the proactive creation and development of both teachers' and future teachers' personality resources [9, 14].

We have chosen the following principles as conceptual guidelines for modeling the training process for innovative educational activities:

- general pedagogical principles (conscientiousness, commitment, continuity, consistency and taking into account individual and age characteristics);

- principles of physical education (health-improving orientation, interconnection of physical education and other types of activities and employment);

- principles of contextual learning (problematicity, joint collective activity and reflexivity) [5].

In turn, the content element presupposes the monitoring of future physical education teachers' level of readiness for this type of activity. It is represented by reflexivepedagogical, coaching and recreational-creative criteria, as well as by optimal, acceptable and unacceptable levels in the model. In order to measure the state of readiness, we have applied T. Ehlers's method, B. Bass's test, A. Lanchins's method, E. Rogov's method, the "Innovative thinking" test, an expert assessment sheet (self-fulfillment in innovative educational activity) and V. Ozerov's method [14-16].

The procedural and technological element reflects the stages of training and the corresponding teaching methods in specific subjects of the curriculum in the specialty 44.03.05 Pedagogical Education (including two training specializations - "Physical Education" and "Health and Safety"). 
The proposed model consists of three stages of training for innovative educational activities. The initial stage (the $1^{\text {st }}$ and $2^{\text {nd }}$ years of training) is aimed at shaping future teachers' innovative orientation to bring up to date the educational environment at school [17]. In accordance with the curriculum, both lectures and tutorials in "Fundamentals of Project Activity", "Theory and Methodology of Physical Education", "Basic Types of Motor Activity" and "Theory and Management of Physical Education at Educational Institutions" provide for the use of active learning methods (role-playing, game design and specific situations' analysis).

At the main stage (the $3^{\text {rd }}$ and $4^{\text {th }}$ years of training), attention is paid to the development of innovative thinking. In his monograph, V.P. Deliya points out the dialectical relationship between the cognitive and instrumental stages of innovative thinking. In particular, the first stage is distinguished by the movement of thought in the direction of creating new knowledge and perceiving its meaning through internal reflection. In turn, the instrumental stage consists in the implementation of new knowledge in the innovative activity [18].

According to A.P. Usoltsev and T.N. Shamalo, innovative thinking is primarily aimed at ensuring innovative activity; therefore it is characterized as creative, scientific-theoretical, socially positive, constructive, transformative and practical thinking [19].

At this stage of training, within the framework of practical exercises and individual tasks in such academic subjects as "Project Activity", "Basic Types of Motor Activity", "Advancing in Pedagogical Physical Education and Sports" and "Innovative Activity in Health Safety Arrangement", it is essential to use the team teaching method and psychomotor teaching methods, such as reproducing movements from memory, "contrasting tasks" and "close tasks" [20].

The final stage (the $5^{\text {th }}$ year of training) is aimed at future physical education teachers' professional potential fulfillment in innovative educational activities: in pedagogical, research and pre-graduation practice, as well as practical classes in such subjects as "Physical Education in Supplementary Education Institutions" and "Sports Activities' Arrangement in Children's Health Camps" [21].

In accordance with the presented model, the purposeful and deliberate training of future physical education teachers will result in their mastering the best possible level of readiness for innovative educational activity.

\section{Conclusion}

The developed structural and logical model is a theoretical construct of future physical education teachers' training. It meets the requirements of the Russian Federation's innovative development. Its implementation is based on the dialectical relationship of methodological, substantive, procedural and logical elements, thus presupposing students' mastering of the best possible level of readiness for innovative educational activities.

The prospects for further research consist in the possibility of testing the developed model and its implementation in the modern process of professional training of Bachelors in Physical Education.

\section{References}

1. Long-term Socio-economic Development Concept of the Russian Federation till 2020, Russia's Government Official Portal, http://government.ru/info/6217 (access date: 17.09.2020) 
2. “Education Development” State Program of the Russian Federation for 2018 - 2025, https://docs.edu.gov.ru/document/3a928e13b4d292f8f71513a2c02086a3/download/13 37/ (access date: 18.09.2020)

3. Strategy of Physical Education and Sports' Development in the Russian Federation till 2030 (draft version). The Official Portal of the Ministry of Sports of the Russian Federation, https://minsport.gov.ru/activities/proekt-strategii-2030/ (access date: 19.09.2020)

4. I.F. Fil'chenkova, D.I. Voronin, Innovative Approaches to General Education Programs' Management in Higher Education, Sovremennye problemy nauki i obrazovaniya, http://www.science-education.ru/ru/article/view?id=11923 (access date: 18.09.2020), 1 (2014)

5. V.V. Ishchuk, Model of Future Physical Education Teachers' Professional Training within the Scope of Contextual and Project-based Learning, Molodoj Uchenyj, https://moluch.ru/archive/61/9209/ (access date: 17.09.2020), 2 (61), 765-769 (2014)

6. R.T. Gadzhimuratova, Future Physical Education Teachers' Functional Competencies Formation Model, Mir Nauki, Kul'tury, Obrazovaniya, 3 (76), 133-136 (2019)

7. P.V. Khomenko, Development and Implementation of the Competence-based Integration and Functional Model of Future Physical Education Specialists' Natural Science Training, International Journal of Experimental Education, http://expeducation.ru/ru/articleview?id=4120 (access date: 20.09.2020), 10-1, 51-57 (2013)

8. N.G. Yershova, S.N. Bekasova, The Use of Innovative Educational Technologies within the Framework of the Competence-based Approach at Universities of Physical Education. Kul'tura fizicheskaya i zdorov'e, 1, 36-39 (2012)

9. I.F. Fil'chenkova, University Teachers' Involvement in Innovative Activities (Monograph, Nizhnij Novgorod, 2017)

10. D.K. Beybalaeva, E.R. Guzueva, B. S. Sadulaeva, Pedagogical Conditions for the Use of Information Technologies in the Process of Training Undergraduate Students for Pedagogical Innovations, Mir nauki, kul'tury, obrazovaniya, 3 (76), 283-285 (2019)

11. V.A. Adol'f, N.F. Il'ina, Teachers' Innovative Activity in the Process of Their Professional Becoming (Monograph, Krasnoyarsk 2007)

12. O.V. Zorina, Physical Education Teachers Professional Training for Innovative Learning Activity, Problemy sovremennogo pedagogicheskogo obrazovaniya. Ser.: Pedagogika i psihologiya, 50 (1), 91-97 (2016)

13. Y. E. Rupasova, The Ability to Innovate as a Priority Professional Skill under Presentday Conditions, Mir nauki, kul'tury, obrazovaniya, 1 (80), 70-72 (2020)

14. O.V. Zorina, Forming Future Physical Education Teachers' Readiness for Innovative Activities, Mir nauki, kul'tury, obrazovaniya, 3 (76), 35-37 (2019)

15. V.P. Ozerov, Forming Human Psychomotor Abilities (Stavropol', 2011)

16. O.V. Antonenko, Fundamentals of Physical Education Teachers' Innovative Educational Activity (Doneck, 2011)

17. I.H. Kurimova, F. Sharifzoda, Teachers as Creators of Goodness and Progress (Dushanbe, 2010)

18. V.P. Deliya, Innovative Thinking in the $21^{\text {st }}$ Century (Monograph, Balashiha, 2011)

19. A.P. Usoltsev, T.N. Shamalo, Innovative Thinking Concept, Pedagogicheskoe obrazovanie v Rossii, 1, 94-98 (2014) 
20. O.V. Zorina, The Use of Psychomotor Teaching Methods in Training Future Physical Education Teachers for Innovative Activities, Mir nauki, kul'tury, obrazovaniya, 1 (80), 75-77 (2019)

21. O.V. Zorina, Pedagogical Technology of Forming Future Physical Education Teachers' Readiness for Innovative Activity, Mir nauki, kul'tury, obrazovaniya, 5 (78), 159-161 (2019) 